\title{
EFEK SAMPING AKSEPTOR KB SUNTIK DEPO MEDROKSI PROGESTERON ASETAT (DMPA) DI BPM FITRI HAYATI
}

\author{
Fitri Yuliastuti Setyoningsih* \\ *Akademi Kebidanan Panca Bhakti \\ email: fitriyuliastuti89@gmail.com
}

\begin{abstract}
Introduction : Injections is a contraceptive method that contains hormones that is injected to the body of women periodically. The Depo Medroxyprogesterone Acetate (DMPA) injections having side effects such as menstrual disorders (amenorrhea, spotting, or menorrhagia), weight gain, vaginal discharge, headaches, and nauseous vomit. The aim of this study is to describe the side effects of DMPA injections contraceptive method in Fitri Hayati private maternity clinic.

Method: The subject of this study was DMPA contraceptive acceptors who visited BPM Fitri Hayati with the total sample were 51 respondents. Variables of this study were the side effects of DMPA contraception namely menstrual disorders (amenorrhea, spotting, or menorrhagia), weight gain, vaginal discharge, headaches, and nauseous vomit. This study was conducted on September - December 2019.

Results : From the total 51 respondents, they who experienced the side effects of injections on menstrual disorders consisting of amenorrhea in the number of 31 respondents (60,8\%), 17 respondents $(33,3 \%)$ experienced spotting, all of the respondent (100\%) were not experience menorrhagia, 18 respondents $(35,3 \%)$ experienced vaginal discharge, 29 respondents (56,9\%) increased their body gain, 18 respondents $(35,3 \%)$ experienced dizziness / headache, and 16 respondents (31,4\%) experienced nausea/vomit.

Conclusion: The majority of DMPA injection acceptors at Fitri Hayati private maternity clinic experienced the side effects.

Suggestion : Health workers are expected to be able to provide health counseling as well as information about contraceptive injection, especially the side effects that will arise from the use of DMPA contraception.
\end{abstract}

Keywords : side effects, family planning acceptors, DMPA injections

\section{ABSTRAK}

Pendahuluan: Kontrasepsi suntikan adalah alat kontrasepsi berupa cairan yang berisi hormon yang disuntikkan kedalam tubuh wanita secara periodik. Kontrasepsi Suntik DMPA ini memiliki efek samping seperti: gangguan haid (berupa amenorea, spotting atau menoragia), terjadinya kenaikan, keputihan, pusing/sakit kepala, serta mual dan muntah. Fitri Hayati.

Tujuan dari penelitian ini adalah untuk mengetahui gambaran efek samping dari KB suntik DMPA di BPM

Metode Penelitian: Subyek penelitian ini adalah akseptor KB suntik DMPA yang mengunjungi BPM Fitri Hayati dengan jumlah sampel 51 responden. Variabel dalam penelitian ini adalah efek samping KB suntik DMPA yaitu amenorea, spotting, menoragia, keputihan, kenaikan berat badan, pusing atau sakit kepala serta mual/muntah. Penelitian ini dilaksanakan pada bulan September sampai bulan Desember 2019.

Hasil penelitian: Dari 51 responden yang mengalami efek samping gangguan haid berupa amenorea yaitu sebesar 31 responden (60,8\%), gangguan haid berupa spotting yaitu sebesar 17 responden (33,3\%), tidak ada yang mengalami efek samping gangguan haid berupa menoragia (100\%), mengalami keputihan yaitu sebesar 18 responden $(35,3 \%)$, mengalami kenaikan berat badan yaitu sebesar 29 responden $(56,9 \%)$, mengalami pusing/sakit kepala yaitu sebesar 18 responden (35,3\%), mual/muntah yaitu sebesar 16 responden $(31,4 \%)$.

Kesimpulan: Mayoritas akseptor KB Suntik DMPA di BPM Fitri Hayati mengalami efek samping.

Saran: Bagi tenaga kesehatan diharapkan dapat memberikan konseling serta informasi tentang KB suntik khususnya efek samping yang akan timbul dari pemakaian kontrasepsi suntik DMPA

Kata Kunci: Efek samping, Akseptor KB, Suntik DMPA 


\section{PENDAHULUAN}

Menurut World Health Organization (WHO), dewasa ini hampir 380 juta pasangan menjalankan Keluarga Berencana dan 65-75 juta diantaranya terutama di negara berkembang menggunakan kontrasepsi hormonal seperti kontrasepsi oral, suntik dan implant. Kontrasepsi hormonal yang digunakan dapat memiliki pengaruh positif ataupun negatif terhadap berbagai organ wanita baik organ genetalia maupun non genetalia (Prawiroharjo, 2014).

Indonesia merupakan salah satu negara berkembang dengan berbagai jenis masalah. Masalah utama yang dihadapi di Indonesia adalah di bidang kependudukan yang masih tingginya pertumbuhan penduduk, dengan 500.000 kelahiran per tahun. Keadaan penduduk yang demikian telah mempersulit usaha peningkatan dan pemerataan kesejahteraan rakyat/pembangunan ekonomi. Semakin tinggi pertumbuhan penduduk semakin besar usaha yang dilakukan untuk mempertahankan kesejahteraan rakyat. Oleh karena itu Pemerintah terus berupaya untuk menekan laju pertumbuhan dengan Program Keluarga Berencana (KB). Gerakan Keluarga Berencana dan pembangunan ekonomi harus dilakukan secara bersamaan untuk mendapatkan hasil pembangunan yang berarti (Manuaba, 2010).

Program Keluarga Berencana menurut UU No 10 tahun 1992 (tentang perkembangan kependudukan dan pembangunan keluarga sejahtera) adalah upaya peningkatan kepedulian dan peran serta masyarakat melalui pendewasaan usia perkawinan (PUP), pengaturan kelahiran, pembinaan ketahanan keluarga, peningkatan kesejahteraan keluarga kecil, bahagia dan sejahtera (Handayani, 2010).

Program Keluarga Berencana (KB) bertujuan untuk mengendalikan pertumbuhan jumlah penduduk di Indonesia. Hal inilah yang menyebabkan berkembangnya berbagai metode kontrasepsi, tetapi tidak semua alat kontrasepsi tersebut bersifat efektif dan aman untuk digunakan. Keluarga Berencana (KB) merupakan salah satu pelayanan kesehatan preventif yang paling dasar dan utama bagi wanita, meskipun tidak selalu diakui demikian. Pelayanan Keluarga Berencana (KB) merupakan salah satu didalam paket Pelayanan Kesehatan Reproduksi Esensial perlu mendapatkan perhatian yang serius, karena dengan mutu pelayanan Keluarga Berencana (KB) berkualitas diharapkan akan dapat meningkatkan tingkat kesehatan dan kesejahteraan (Handayani, 2010).

Secara nasional pada tahun 2017 pasangan usia subur sebanyak 37.338 .265 , dengan peserta
KB aktif sebanyak 23.606.218. Presentase untuk masing-masing adalah IUD 1.688 .685 (7.15\%), MOW 655.762 (2,78\%), MOP 124.262 (0,53\%), Implan 1.650.227 (6,99\%), Suntik 14.817 .663 (62,77\%), Kondom 288.388 (1,22\%), Pil 4.069 .844 $(17,24 \%)$ (Kemenkes RI, 2018).

Kontrasepsi Suntik DMPA ini memiliki efek samping seperti: gangguan haid (berupa amenorea, spotting atau menoragia), terjadinya kenaikan atau penurunan berat badan, mengalami depresi, keputihan, timbulnya jerawat pada wajah, rambut mengalami kerontokan, pusing/sakit kepala, mual dan muntah, serta perubahan libido/dorongan seksual. Efek samping ini akan timbul dan paling sering ( $57 \%$ dalam 3 bulan pertama) adalah ketidak teraturan haid (perdarahan tidak teratur, sering, dan/atau berkepanjangan), yang membaik setelah 3 bulan atau lebih setelah setahun pertama ( $30 \%$ dari pengguna akan terus mengalami ketidak teraturan). Sakit kepala, nyeri tekan payudara, jerawat, keputihan dan perubahan mood mereda setelah 3 bulan pertama (Sinclair, 2010).

Di Provinsi Lampung pada tahun 2017 jumlah Pasangan Usia Subur (PUS) sebanyak 1.221.376 dengan peserta KB aktif sebanyak 840.666. Presentase penggunaan alat kontrasepsi IUD sebanyak $35.250(4,19 \%)$, MOW sebanyak $6.227(0,74 \%)$, MOP sebanyak 3.163 (0,38\%), Implan sebanyak $74.879(8,91 \%)$, suntik sebanyak $588.843(70,04 \%)$, kondom sebanyak 7.146 $(0,85 \%)$, dan pil sebanyak $118.739(14,12 \%)$ ( Kemenkes RI, 2018).

Menurut study pendahuluan yang dilakukan di BPM Fitri Hayati dari 10 akseptor KB yang ditemui lebih dari $50 \%$ mengalami efek samping dari penyuntikan. Salah satu efek sampingnya adalah kenaikan berat badan dan gangguan haid.

\section{METODE PENELITIAN}

Jenis penelitian yang dilakukan adalah penelitian deskriptif dengan pendekatan cross sectional. Teknik pengambilan sample yang digunakan adalah total sampling. Penelitian ini dilakukan dari bulan September sampai bulan Desember 2019 di BPM Fitri Hayati. Data yang diperoleh merupakan data primer yang didapatkan langsung dari responden. Subyek pada penelitian ini adalah akseptor KB suntik DMPA yang berada di BPM Fitri Hayati dengan total responden 51 responden. Variabel pada penelitian ini adalah efek samping KB suntik DMPA antara lain: amenorea, spotting, menoragia, keputihan, kenaikan berat badan, pusing atau sakit kepala serta mual/muntah. Jenis penelitian ini adalah diskriptif dengan pendekatan cross sectional. Metode yang 
digunakan dalam pengumpulan data pada penelitian ini adalah data primer yang diperoleh dengan metode wawancara disertai dengan instrumen checklist. Analisa data yang digunakan adalah analisa univariat.

\section{HASIL PENELITIAN \\ Karakteristik}

Tabel 1.

Distrubusi frekuensi usia responden dan lama pemakaian kontrasepsi DMPA

\begin{tabular}{lcc}
\hline \multicolumn{1}{c}{ Variable } & Frekuensi & $\begin{array}{c}\text { Presentase } \\
(\%)\end{array}$ \\
\hline Usia & & \\
$<20$ tahun & 2 & 3,9 \\
20-35Ahun & 35 & 68,6 \\
> 35 tahun & 14 & 27,5 \\
Lama pemakaian & & \\
kontrasepsi & & \\
< 1 Tahun & 10 & 19,6 \\
$>$ 1 Tahun & 41 & 80,4 \\
\hline
\end{tabular}

Berdasarkan tabel 1 distribusi frekuensi usia responden kontrasepsi suntik DMPA bahwa dari 51 $(100 \%)$ responden akseptor KB suntik DMPA yang paling banyak menggunakan kontrasepsi suntik DMPA ialah usia reproduksi (20-35 tahun) sebanyak $35(68,6 \%)$ responden. Sedangkan untuk lama pemakaian kontrasepsi suntik DMPA bahwa dari $51(100 \%)$ responden akseptor KB suntik DMPA yang paling banyak menggunakan kontrasepsi DMPA dengan lama pemakaian kontrasepsi DMPA yaitu > 1 Tahun pemakain sebanyak $41(80,4 \%)$ responden.

\section{Efek Samping KB Suntik DMPA}

Berdasarkan hasil penelitian diketahui bahwa mayoritas responden mengalami amenorea sebanyak $32(60,8 \%)$ responden, terjadi spotting sebanyak $17(33,3 \%)$ responden, tidak ada yang mengalami menoragia, terjadi keputihan sebanyak $18(35,3 \%)$ responden, terjadi kenaikan berat badan sebanyak $29(56,9 \%)$ responden, terjadi pusing atau sakit kepala $18(35,3 \%)$ responden dan terjadi mual muntah sebanyak $16(31,4 \%)$ responden.
Tabel 2

Distribusi frekuensi efek samping KB Suntik DMPA

\begin{tabular}{lcc}
\hline \multicolumn{1}{c}{ Variabel } & Frekuensi & $\begin{array}{c}\text { Presentase } \\
(\%)\end{array}$ \\
\hline Amenorea & 31 & 60,8 \\
Terjadi & 20 & 39,2 \\
Tidak Terjadi & 17 & 33,3 \\
Spotting & 34 & 66,7 \\
Terjadi & & \\
Tidak Terjadi & 0 & 0 \\
Menoragia & 51 & 100 \\
Terjadi & & \\
Tidak Terjadi & 18 & 35,3 \\
Keputhan & 33 & 64,7 \\
Terjadi & & \\
Tidak Terjadi & 29 & 56,9 \\
Kenaikan Berat Badan & 22 & 43,1 \\
Terjadi & & \\
Tidak Terjadi & 18 & 35,3 \\
Pusing atau Sakit Kepala & 33 & 64,7 \\
Terjadi & & \\
Tidak Terjadi & & 31,4 \\
Mual/Muntah & 16 & 68,6 \\
\hline Terjadi & 35 & \\
Tidak Terjadi & &
\end{tabular}

\section{PEMBAHASAN}

\section{Karakteristik Responden}

Berdasarkan tabel 1 distribusi frekuensi usia responden kontrasepsi suntik DMPA bahwa dari 51 $(100 \%)$ responden akseptor KB suntik DMPA yang paling banyak menggunakan kontrasepsi suntik DMPA ialah usia reproduksi (20-35 tahun) sebanyak $35(68,6 \%)$ responden sedangkan responden yang memiliki usia $<20$ tahun hanya 2 $(3,9 \%)$ responden yang berusia $>35$ tahun sebanyak $14(27,5 \%)$ responden. Saifuddin (2010) mengemukakan usia reproduksi sehat seorang wanita adalah antara 20-35 tahun. Hasil penelitian ini menunjukkan bahwa sebagian besar responden termasuk dalam kategori reproduksi sehat, yaitu usia bereproduksi yang memiliki resiko yang rendah untuk ibu dan anak. Usia mempengaruhi aksptor dalam penggunaan alat kontrasepsi. Menurut Hartanto (2010) usia adalah lamanya hidup seseorang yang dihitung dari kelahiran sampai dengan saat ini. Usia mempengaruhi akseptor dalam menggunakan alat kontrasepsi. Dari usia dapat ditentukan fase-fase. Usia kurang dari 20 tahun yaitu fase menunda kehamilan, usia 20-30 tahun yaitu fase menjarangkan kehamilan, usia 30 adalah fase mengakhiri kesuburan.

Menurut Septianingrum (2018) pada penelitannya mengatakan bahwa mayoritas akseptor KB berusia reproduktif dan menunjukkan 
hasil bahwa faktor usia merupakan faktor yang paling mempengaruhi terhadap tingginya akseptor KB suntik 3 bulan dibandingkan dengan faktor pendidikan, pekerjaan, pendapatan, dan paritas. Hal ini juga sejalan dengan hasil penelitian dari Prihati (2019) yang menuliskan bahwa mayoritas responden yaitu akseptor KB suntik berusia $<35$ tahun atau reproduksi sehat.

Dapat disimpulkan bahwa pada penelitian ini menunjukkan bahwa sebagian besar responden masuk dalam kategori reproduksi sehat sehingga memiliki resiko yang rendah untuk akseptor KB dibandingkan dengan akseptor KB yang berusia relatif tua.

Berdasarkan tabel 1 distribusi frekuensi berdasarkan lama pemakaian kontrasepsi suntik DMPA bahwa dari 51 (100\%) responden akseptor KB suntik DMPA yang paling banyak menggunakan kontrasepsi DMPA dengan lama pemakaian kontrasepsi DMPA yaitu $>1$ Tahun pemakain sebanyak $41 \quad(80,4 \%)$ responden sedangkan responden yang meggunakan kontrasepsi suntik DMPA $\leq 1$ Tahun yaitu sebanyak $10(19,6 \%)$ responden.

Lamanya pemakaian kontrasepsi mempengaruhi kejadian efek samping yang akan timbul pada akseptor. Semakin lama pemakaian kontrasepsi maka semakin besar kejadian efek samping yang akan timbul pada akseptor KB suntik tersebut (Hartanto 2010). Hal ini sejalan dengan penelitian Hanifah (2014) yang menunjukkan bahwa rata-rata responden memakai KB suntik 3 bulan lebih dari 2 tahun dan ada hubungan yang positif antara lama pemakaian kontrasepsi suntik dengan salah satu efek samping suntik yaitu peningkatan berat badan. Semakin lama penggunaan suntik KB semakin meningkatnya berat badan.

\section{Gangguan haid berupa amenorea (tidak mendapat haid)}

Berdasarkan tabel 2 distribusi frekuensi kejadian efek samping kontrasepsi suntik DMPA karena gangguan haid berupa amenorea (tidak mendapat haid) bahwa dari $51(100 \%)$ responden akseptor suntik DMPA yang mengalami efek samping gangguan haid karena amenorea yaitu 31 $(60,8 \%)$ responden dan $20 \quad(39,2 \%)$ tidak mengalami. Sebagaimana diungkapkan oleh Prawirohardjo (2014) bahwa suntik KB dapat menyebabkan amenorea karena KB suntik ini membuat wanita tidak mampu menghasilkan ovum, sehingga proses ovulasi tidak terjadi yang pada akhirnya wanita akan mengalami gangguan hormon. Selain itu, gangguan haid berupa amenorea pada akseptor KB suntik juga bisa disebabkan karena progesteron dalam komponen DMPA menekan LH sehingga endometrium menjadi lebih dangkal dan atropis dengan kelenjar-kelenjar yang tidak aktif.

Dari hasil evaluasi penggunaan kontrasepsi suntik pada pasangan usia subur (PUS) oleh Rumende (2015) menyebutkan bahwa efek samping yang paling banyak dialami oleh akseptor KB suntik DMPA adalah amenorea (tidak haid) dengan presentase $72,58 \%$. Hal ini sejalan dengan penelitian oleh Sari (2015) yang mendapatkan hasil $50 \%$ dari responden akseptor KB suntik DMPA mengalami gangguan haid berupa amenorea (tidak mendapat haid).

Dapat disimpulkan bahwa akseptor KB suntik DMPA mayoritas akan mengalami gangguan haid berupa amenorea (tidak mendapatkan haid), hal ini dapat terlihat dari hasil penelitian dan juga penelitian terdahulu. Selain itu juga dari teori juga menyebutkan bahwa penebab amenorea karena adanya gangguan hormon yang terkandung di dalam suntik DMPA.

\section{Spotting (perdarahan bercak/ngeflek-flek)}

Berdasarkan tabel 2 distribusi frekuensi kejadian efek samping kontrasepsi suntik DMPA karena gangguan haid berupa spotting bahwa dari $51 \quad(100 \%)$ responden yang mengalami efek samping gangguan haid berupa spotting yaitu 17 $(33,3 \%)$ responden. Sedangkan yang tidak mengalami efek samping spotting sebanyak 34 $(66,7 \%)$ responden. Menurut Hartanto (2010), Spotting merupakan perdarahan inter-menstrual yang jumlahnya sedikit sekali sehingga tidak memerlukan pemakaian tampon atau kain/kasa pembalut). Penyebab lain dari spotting adalah ketidakseimbangan hormon dan diperkirakan karena kerja enzim plasmin yang terkonsentrasi di jaringan selaput lendir rahim. Enzim ini bersifat fibrinolitik (menghancurkan fibrin yang berguna untuk pembentukan darah). Perdarahan bercak juga diduga terjadi penurunan kadar estrogen prahaid.

Dari hasil penelitian Laila (2019) menyebutkan bahwa sebagian besar responden mengalami spotting di dalam waktu menstruasi yaitu sebanyak $66,7 \%$. Hal ini juga sejalan dengan penelitian Dewi (2018) yang menyebutkan bahwa $23,7 \%$ responden akseptor KB suntik DMPA mengalami gangguan haid berupa spotting.

Tidak ada kesenjangan antara teori, hasil penelitian maupun penelitian terdahulu yang menyebutkan bahwa akseptor KB suntik DMPA mayoritas akan mengalami spotting yang 
disebabkan oleh ketidak seimbangan hormon yang terjadi setelah pemakaian KB suntik.

\section{Menoragia (perdarahan lebih banyak atau lebih lama dari biasanya).}

Berdasarkan tabel 2 distribusi frekuensi kejadian efek samping kontrasepsi suntik DMPA karena gangguan haid berupa menoragia dari 51 $(100 \%)$ responden tidak ada yang mengalami efek samping gangguan haid berupa menoragia.

Menoraghi terjadi karena ketidakseimbangan hormonal karena penambahan progesteron sehingga menyebabkan kadar estrogen dalam tubuh kurang optimal. Kadar estrogen dalam tubuh yang kurang optimal tersebut pada akhirnya menyebabkan terjadinya widral progesteron, wanita yang menggunakan progesteron kerja lama, maka perdarahan irreguler baru akan terjadi apabila kadar hormon steroid yang dilepas berada di bawah 20 $\mathrm{mg} / 24$ jam dan profil hormonal berada dalam aktivitas luteal (Baziad, 2008).

Hasil penelitian ini tidak sejalan dengan penelitian menurut Sihombing (2019) pada penelitiannya mengatakan bahwa responden mengalami gangguan haid sebanyak 39 (39.8\%). Hal ini dimungkinkan karena adanya faktor lain yang bisa menyebabkan terjadinya menoragia atau gangguan haid, salah satunya karena faktor psikologis.

\section{Keputihan}

Berdasarkan tabel 2 distribusi frekuensi kejadian efek samping kontrasepsi suntik DMPA berupa keputihan bahwa dari $51(100 \%)$ responden yang mengalami efek samping kontrasepsi suntik DMPA karena keputihan yaitu $18 \quad(35,3 \%)$ responden, Sedangkan yang tidak mengalami efek samping keputihan sebanyak $33 \quad(64,7 \%)$ responden.

Hal ini sesuai dengan Rahayu (2018) dalam penelitiannya menyebutkan bahwa terdapat 4,9\% akseptor KB suntik DMPA yang mengalami efek samping keputihan. Keputihan timbul karena Efek dari penyuntikan hormon progesteron akan merubah flora dan $\mathrm{PH}$ vagina, sehingga jamur mudah tumbuh di dalam vagina dan menimbulkan keputihan. Oleh sebab itu responden yang mengalami keputihan harus lebih menjaga personal hygien untuk mencegah timbulnya keputihan (Varney, 2007).

Dapat disimpulkan bahwa pada penelitian ini sejalan dengan penelitian sebelumnya yang menjelaskan bahwa beberapa dari akseptor KB suntik DMPA akan mengalami efek samping keputihan. Hal ini bisa disebabkan karena pengaruh hormon progesteron yang terkandung di dalam suntik DMPA, selain itu juga bisa terjadi karena kurangnya personal higiens yang tepat.

\section{Kenaikan berat badan}

Berdasarkan tabel 2 distribusi frekuensi kejadian efek samping kontrasepsi suntik DMPA berupa kenaikan berat badan bahwa dari 51 (100\%) responden yang mengalami efek samping kontrasepsi suntik DMPA karena kenaikan berat badan yaitu sebesar $29(56,9 \%)$ responden, yang tidak mengalami efek samping kenaikan berat badan sebanyak $22(43,1 \%)$ responden. Hal ini sesuai dengan teori yang dikemukakan oleh Hartanto (2010), bahwa progesteron merangsang pusat pengendalian nafsu makan di hipothalamus yang menyebabkan akseptor makan lebih banyak daripada biasanya. Hanifah (2014) mengatakan bahwa hasil penelitian menunjukkan bahwa ratarata peningkatan berat badan $8,68 \mathrm{~kg}$ dengan kenaikan terendah sebanyak $5 \mathrm{~kg}$ dan tertinggi 17 $\mathrm{kg}$.

Hal ini sejalan dengan penelitian Roza (2019) yang mengatakan bahwa mayoritas akseptor KB suntik DMPA $(65,1 \%)$ mengalami kenaikan berat badan, serta ada hubungan yang bermakna antara penggunaan kontrasepsi suntik DMPA terhadap peningkatan berat badan. Hal ini sejalan dengan penelitian Laila (2019) yang mengatakan bahwa mayoritas responden mengalami kenaikan berat badan yaitu sebanyak $72,7 \%$ responden.

Dapat disimpulkan bahwa efek samping dari KB suntik DMPA mayoritas akseptor akan mengalami kenaikan berat badan. Hal ini bisa terlihat dari beberapa penelitian dan juga dari teori yang menyebutkan bahwa hormon progesteron akan merangsang nafsu makan sehingga bisa meyebabkan kenaikan berat badan.

\section{Pusing atau sakit kepala}

Berdasarkan tabel 2 distribusi frekuensi kejadian efek samping kontrasepsi suntik DMPA berupa pusing/sakit kepala bahwa Dari 51 (100\%) responden yang mengalami efek samping kontrasepsi suntik DMPA berupa pusing/sakit kepala yaitu sebesar 18 (35,3\%) responden, Sedangkan yang tidak mengalami efek samping pusing/sakit kepala sebanyak $33 \quad(64,7 \%)$ responden. Menurut Suratun (2008) sakit kepala bisa disebabkan karena reaksi tubuh terhadap hormon progesteron yang terdapat pada kb suntik DMPA.

Pada penelitiannya Sari (2015) menuliskan bahwa 14,3\% akseptor KB suntik DMPA mengalami efek samping sakit kepala. Bisa disimpulkan bahwa 
dari hasil penelitian dan penelitian terdahulu memiliki kesamaan yaitu akseptor KB suntik DMPA sebagian akan mengalami efek samping yaitu pusing/sakit kepala, yang terjadi akibat dari hormon progesteron yang akan membuat ketidakseimbangan hormon yang memicu sakit kepala.

\section{Mual atau muntah}

Berdasarkan tabel 2 distribusi frekuensi kejadian efek samping kontrasepsi suntik DMPA berupa mual/muntah bahwa dari $51 \quad(100 \%)$ responden yang mengalami efek samping kontrasepsi suntik DMPA karena mual/muntah yaitu sebesar $16(31,4 \%)$ responden Sedangkan yang tidak mengalami efek samping mual/muntah sebanyak $35(68,6 \%)$ responden. Mual yang terjadi pada akseptor tidak menggangu aktifitas seharihari. Pada bulan-bulan pertama penyuntikan tubuh akan bereaksi terhadap hormon progesteron yang bisa mempengaruhi produksi asam lambung (Irianto, 2014).

Pada penelitian yang dilakukan oleh Rusminah (2018) menyatakan bahwa akseptor KB suntik mengalami efek samping mual muntah sebanyak $41,2 \%$. Hal ini juga sejalan dengan penelitian Rahayu (2017) yang menyatakan bahwa akseptor KB suntik DMPA sebanyak 2,7\% mengalami mual/muntah. Dapat disimpulkan bahwa hasil penelitian ini dan penelitian sebelumnya memiliki kesamaan yaitu akseptor KB DMPA mengalami efek samping mual/muntah. Hal ini juga sesuai dengan teori yang ada. Mual/muntah ini biasanya akan dirasakan oleh akseptor KB pada awal penyuntikan.

\section{KESIMPULAN}

Dari 51 responden yang mengalami efek samping gangguan haid berupa amenorea yaitu sebesar 31 responden $(60,8 \%)$ sendangkan yang tidak mengalami efek samping amenorea sebanyak 20 responden $(39,2 \%)$, yang mengalami efek samping gangguan haid berupa spotting yaitu sebesar 17 responden (33,3\%), tidak ada yang mengalami efek samping gangguan haid berupa menoragia (100\%), mengalami efek samping keputihan yaitu sebesar 18 responden $(35,3 \%)$, mengalami efek samping kontrasepsi suntik DMPA berupa kenaikan berat badan yaitu sebesar 29 responden $(56,9 \%)$, mengalami efek samping kontrasepsi suntik DMPA berupa pusing/sakit kepala yaitu sebesar 18 responden $(35,3 \%)$, mengalami efek samping kontrasepsi suntik DMPA berupa mual/muntah yaitu sebesar 16 responden $(31,4 \%)$

\section{SARAN}

Bagi tenaga kesehatan diharapkan dapat memberikan konseling serta informasi tentang KB suntik khususnya efek samping yang akan timbul dari pemakaian kontrasepsi suntik DMPA, serta dari hasil penelitian ini dapat dijadikan gambaran maupun pertimbangan dalam membuat program untuk meningkatkan pengetahuan serta dapat memahami apa yang sedang akseptor KB suntik alami untuk penelitian selanjutnya.

\section{DAFTAR PUSTAKA}

Baziad, A. (2008). Kontrasepsi Hormonal. Jakarta: Bina Pustaka Sarwono Prawiroharjo.

Dewi, A. D. C. (2018). GAMBARAN EFEK SAMPING KB SUNTIK DEPO MEDROKSI PROGESTERON ASETAT PADA AKSEPTOR. Jurnal'Aisyiyah Medika, 2(1).

Handayani, S. (2010). Buku ajar pelayanan keluarga berencana. Yogyakarta: Pustaka Rihama, 76.

Hanifah, A., \& Sumini, S. (2014). HUBUNGAN LAMA PEMAKAIAN KB SUNTIK 3 BULAN DENGAN PENINGKATAN BERAT BADAN. Jurnal IImiah Permas: Jurnal IImiah STIKES Kendal, 4(1), 1-8.

Hartanto, H. (2004). Keluarga berencana dan kontrasepsi. Jakarta: Pustaka Sinar Harapan, 37.

Irianto, K. (2011). Keluarga Berencana. Bandung: Mediana Sarana Cerdas.

Kemenkes RI. (2018). Data dan Informasi Profil Kesehatan Indonesia Tahun 2017. Jakarta: Kementrian RI 2018

Laila, N. (2019). ANALISIS FAKTOR YANG BERHUBUNGAN DENGAN KEJADIAN DROPOUT KONTRASEPSI SUNTIK 3 BULAN DI PUSKESMAS MOJO SURABAYA (Doctoral dissertation, Universitas Airlangga).

Manuaba, I. B. G. (2010). IImu kebidanan, penyakit kandungan dan keluarga berencana. Jakarta: EGC, 15, 157.

Wiknjosastro, I. K. (2007). Penerbit Yayasan Bina Pustaka Sarwono Prawirohardjo.

Prihati, D. R., \& Nikmah, U. N. (2019). Gambaran Akseptor Sekaitan Dengan Kontrasepsi Suntik Di Klaten. Jurnal Kebidanan dan Kesehatan Tradisional, 4(1), 6-11.

Rahayu, S. (2018). EFEK SAMPING KONTRASEPSI SUNTIK CYCLOFEM DAN DMPA. Babul IImi Jurnal IImiah Multi Science Kesehatan, 9(3).

Rahayu, T. B., \& Wijanarko, N. (2017). Efek Samping Akseptor Kb Suntik Depo Medroksi 
Progesterone Acetat (Dmpa) Setelah 2 Tahun Pemakaian. Jurnal Kesehatan Samodra IImu, 8(1), 32-38.

Roza, E., \& Atzmardina, Z. (2019). Hubungan penggunaan kontrasepsi suntik DMPA dengan peningkatan berat badan pada akseptor di Puskesmas Tapus Sumatera Barat tahun 2017. Tarumanagara Medical Journal, 2(1), 37-42.

Rumende, I. T. (2015). Evaluasi Penggunaan Kontrasepsi Suntik Pada Pasangan Usia Subur (Pus) Di Kelurahan Walian I Tomohon. PHARMACON, 4(1).

Rusminah, R., Susanti, E. T., \& Yuliyanti, D. (2018). EFEK SAMPING KONTRASEPSI SUNTIK DEPO MEDROXY PROGESTERONE ASETAT (DMPA) DAN CYCLOFEM PADA AKSEPTOR KB SUNTIK. Jurnal Keperawatan Karya Bhakti, 4(1), 21-24.

Saifuddin, A. B. (2003). Buku Panduan Praktis Pelayanan Kontrasepsi: Yayasan Bina Pustaka Sarwono Prawirohardjo.
Sari, S. W., Suherni, S., \& Purnamaningrum, Y. E. (2015). Gambaran efek samping kontrasepsi suntik pada akseptor KB suntik. Jurnal Kesehatan Ibu dan Anak, 8(2).

S Septianingrum, Y., Wardani, E. M., \& Kartini, Y. (2018). Faktor-Faktor yang Mempengaruhi Tingginya Akseptor KB Suntik 3 Bulan. Jurnal Ners dan Kebidanan (Journal of Ners and Midwifery), 5(1), 015-019.

Sihombing, S. (2019). Hubungan Pemakaian KB Suntik 3 Bulan dengan Gangguan Haid di Puskesmas Baloi Permai Kota Batam. Jurnal Keperawatan. 9 (1). 1120-1123

Sinclair, C. (2010). Buku Saku Kebidanan. Jakarta: EGC

Suratun. 2008. Pelayanan Keluarga Berencana dan Pelayanan Kontrasepsi. Jakarta: Trans Info Media

Varney, H. (2006). Buku Ajar Asuhan Kebidanan Edisi 4. Jakarta: EGC. 